\title{
Filamentous Green Algae Reduce Walleye Fingerling Production in Earthen-Substrate Ponds
}

\author{
Matthew J. Ward, Ryan A. Rasmus \\ South Dakota Department of Game, Fish and Parks, Blue Dog State Fish Hatchery, Waubay, USA \\ Email: matthew.ward@state.sd.us
}

How to cite this paper: Ward, M.J. and Rasmus, R.A. (2021) Filamentous Green Algae Reduce Walleye Fingerling Production in Earthen-Substrate Ponds. Open Journal of Animal Sciences, 11, 157-163. https://doi.org/10.4236/ojas.2021.112012

Received: January 29, 2021

Accepted: April 5, 2021

Published: April 8, 2021

Copyright $\odot 2021$ by author(s) and Scientific Research Publishing Inc. This work is licensed under the Creative Commons Attribution International License (CC BY 4.0).

http://creativecommons.org/licenses/by/4.0/

\section{(c) (i) Open Access}

\begin{abstract}
Reduced walleye (Sander vitreus) fingerling production possibly related to nuisance filamentous green algae and overly stable water chemistry patterns is a concern in earthen-substrate ponds at Blue Dog State Fish Hatchery, South Dakota, USA. We describe the success of alfalfa (Medicago sativa) meal (AFM, $\mathrm{n}=2$ ), alfalfa meal plus soybean (Glycine max) meal (AFM + SBM, $\mathrm{n}$ $=1)$, and alfalfa meal plus liquid $28 \mathrm{~N}: 0 \mathrm{P}: 0 \mathrm{~K}(\mathrm{AFM}+28: 0: 0, \mathrm{n}=1)$ at achieving walleye production objectives ( $>104,000$ walleye and 32 kilograms/hectare) as well as the occurrence of filamentous green algae and the associated patterns of ammonia-nitrogen, $\mathrm{pH}$, and dissolved oxygen in earthen-substrate ponds. Walleye production objectives were only achieved when filamentous green algae were absent preceding harvest, which occurred in one pond that received AFM and in the pond that received AFM + 28:0:0. The presence of filamentous green algae preceding harvest was associated with higher dissolved oxygen and $\mathrm{pH}$, whereas declines in these variables occurred when filamentous green algae were absent. Organic fertilizer alone exhibited low ammonia-nitrogen $(<0.1 \mathrm{mg} / \mathrm{L})$ despite the substitution of higher protein content soybean meal, but supplementation with 28:0:0 increased ammonia-nitrogen to $0.23 \mathrm{mg} / \mathrm{L}$. These findings highlight the reduction in walleye fingerling production that occurred in the presence of filamentous green algae and the unpredictability of results when two earthen-substrate ponds are treated exactly the same with alfalfa meal. Achievement of walleye production objectives, lack of nuisance filamentous green algae, and promotion of favorable patterns in water chemistry warrant future experimentation with alfalfa meal supplemented with 28:0:0 in earthen-substrate ponds at this hatchery.
\end{abstract}

\section{Keywords}

Filamentous Green Algae, Walleye, Pond Culture 


\section{Introduction}

Earthen-substrate ponds at Blue Dog State Fish Hatchery (BDSFH) have historically received alfalfa (Medicago sativa) fertilizer to promote food webs that nourish walleye (Sander vitreus) fingerlings to approximately $30 \mathrm{~mm}$ total length [1]. Nuisance filamentous green algae (e.g., Hydrodictyon, Cladophora, Pithophora) can occur in these ponds, which reduce fish production through physical entanglement [2] and utilization of nutrients that are not directed into prey for fish. The presence of filamentous green algae during pond draining also increases workload and labor costs when screens regularly become plugged. Overall, filamentous green algae reduce efficiencies of hatchery pond production.

Lined-substrate ponds, also at BDSFH, respond differently when fertilized with alfalfa compared to earthen-substrate ponds. Higher ammonia-nitrogen combined with decreasing $\mathrm{pH}$ and dissolved oxygen can occur during the second half of the approximate 35-day culture interval [3]. Moreover, lined ponds enhance walleye fingerling harvest metrics [3] [4] and generally lack filamentous algae during pond harvest (unpublished data from BDSFH). Thus, manipulating fertilizer regimens in earthen ponds to achieve these water chemistry patterns may reduce the likelihood of filamentous green algae, while improving walleye fingerling production.

Here, we describe the success of alfalfa meal (AFM), alfalfa meal plus soybean (Glycine max) meal (AFM + SBM) and alfalfa meal plus liquid 28N:0P:0K (AFM $+28: 0: 0)$ at achieving walleye production objectives (>104,000 walleye and 32 kilograms/hectare) as well as the occurrence of filamentous green algae and associated patterns in ammonia-nitrogen, $\mathrm{pH}$, and dissolved oxygen in earthen-substrate ponds.

\section{Methods}

\subsection{Study Site, Design, and Fertilizer}

This study was conducted in four, 0.72-ha earthen-substrate ponds at BDSFH, Waubay, South Dakota, USA during 2019. All ponds were filled with unfiltered Blue Dog Lake water and initially fertilized on May 14 before being stocked with 208,333 walleye fry/ha on May 15. The AFM treatment was used in two ponds (30 and 34), while AFM + SBM and AFM + 28:0:0 treatments were each used in one pond. The timeline for fertilizer application and amounts of alfalfa (17\% protein, Green Meadows Forage, Gayville, South Dakota, USA) and soybean (46\% protein, Famo Feeds, Inc. Freeport, Minnesota, USA) meal used are presented in Table 1. Additionally, initial fertilization on May 14 included 23 kilograms of yeast (15\% protein, Dakota Yeast, LLC, Wahpeton, North Dakota, USA) in all ponds. In the AFM + 28:0:0 treatment, the first two applications of 28:0:0 (May 28 and June 5) were made with a target concentration of 1000 $\mathrm{mg} / \mathrm{m}^{3}(1.0 \mathrm{mg} / \mathrm{L})$ of inorganic nitrogen. All subsequent 28:0:0 applications were made with a target concentration of $600 \mathrm{mg} / \mathrm{m}^{3}(0.6 \mathrm{mg} / \mathrm{L})$ inorganic nitrogen. To determine the volume of 28:0:0 to apply, a HachDR2010 Spectrophotometer 
Table 1. Timeline and amount (kilograms) of fertilizer applied in three treatments (alfalfa meal, AFM; alfalfa meal plus soybean meal, AFM + SBM; alfalfa meal plus 28:0:0, AFM + 28:0:0) used in four, 0.72-hectare earthen-substrate ponds during 2019. All soybean meal amounts applied are underlined, while the volume of 28:0:0 applied is not specified because it varied depending upon inorganic nitrogen concentration in the pond water and target concentration (see methods). All other numbers indicate alfalfa meal amounts. Ponds were harvested on June 18 or 19.

\begin{tabular}{cccccc}
\hline Treatment & May 14 & May 24 & May 28 & June 3 & June 5, 10, 12, 14 \\
\hline AFM (Pond 30 and 34) & 249 & 136 & & 113 & \\
AFM + $\underline{\text { SBM }}$ & 249 & $\underline{136}$ & & $\underline{113}$ & \\
AFM + 28:0:0 & 249 & 136 & 28:0:0 applied & 113 & 28:0:0 applied \\
\hline
\end{tabular}

(Loveland, Colorado, USA) was first used to measure ammonia-nitrogen (mg/L, salicylate method) and nitrate-nitrogen $(\mathrm{mg} / \mathrm{L}$, cadmium reduction method) within pond water. These values were converted and used in the following equation where the target, ammonia-nitrogen, and nitrate-nitrogen concentrations are in milligrams per cubic meter. Pond volume was assumed to be 8437 cubic meters based on historical hatchery estimates and nitrogen concentration of 28:0:0 fertilizer was 456,000 milligrams per liter based on label specifications including fertilizer density of 1.27 kilograms per liter that is $28 \%$ nitrogen and has a specific gravity of 1.281 .

$$
\begin{aligned}
& \text { Liters of 28:0:0 required } \\
& =((\text { target concentration })-(\text { ammonia-nitrogen concentration }) \\
& -(\text { nitrate-nitrogen concentration })) \\
& \quad \times \text { pond volume/nitrogen concentration in 28:0:0 }
\end{aligned}
$$

\subsection{Water Chemistry}

Dissolved oxygen (Oakton PD 450 meter with RDO probe and sensor cap, Oakton Instruments, Vernon Hills, Illinois), pH (Oakton pH 150 meter with electrode, Oakton Instruments, Vernon Hills, Illinois), and water temperature (same equipment as dissolved oxygen) were measured in all ponds beginning on May 17. Subsequent measurements occurred on weekdays in each pond beginning at 1400 hours but were typically not made on the weekends or observed holidays. In addition, water temperature was recorded at pond stocking (May 15). Ammonia-nitrogen (same method as aforementioned) was measured in all ponds once a week beginning on May 20. All water quality measurements were made at the drain structure of each pond to standardize collection. Ammonia-nitrogen was determined from a 1-liter water sample collected 0.15 meters beneath the surface, while $\mathrm{pH}$, dissolved oxygen, and temperature were measured with their respective probes at a depth of $0.10(\mathrm{pH})$ and 1.00 meter (dissolved oxygen and temperature). All variables were plotted over time to describe patterns in water quality within each pond. 


\subsection{Filamentous Green Algae}

The presence or absence of filamentous green algae within each pond was noted approximately one week prior to pond harvest. All ponds were viewed by an observer standing on top of the drain structure when the weather conditions were sunny and calm.

\subsection{Walleye Harvest Metrics and Production Objectives}

For each pond, a known number of walleyes $(\geq 150)$ was randomly removed from the catch basin and cumulatively weighed to determine the number of walleyes per kilogram. The number of walleye (WAE) harvested from each pond was estimated as,

$\mathrm{WAE}=$ number of walleye $/$ kilogram $\times$ total kilograms harvested .

The objective for each pond was to achieve at least 104,000 walleyes and 32 kilograms per hectare. Ponds were harvested on June 18 or 19.

\section{Results}

Walleye production objectives were achieved in the AFM (Pond 34) and AFM + 28:0:0 ponds when filamentous green algae were absent (Table 2). Likewise, both dissolved oxygen and $\mathrm{pH}$ declined around June 5 in these ponds (Figure 1(a) and Figure 1(b)). However, when filamentous green algae were present, walleye harvest objectives were not achieved (Table 2) and this coincided with patterns in dissolved oxygen and $\mathrm{pH}$ that either remained high (i.e., $>9.5 \mathrm{mg} / \mathrm{L}$; Figure 1(a)) or increased throughout the culture period (Figure 1(b)).

Ammonia-nitrogen began similarly low $(<0.05 \mathrm{mg} / \mathrm{L})$ in all ponds and remained $<0.1 \mathrm{mg} / \mathrm{L}$ except in the pond that received 28:0:0 supplementation which measured $0.23 \mathrm{mg} / \mathrm{L}$ on June 10 (Figure $1(\mathrm{c})$ ).

Water temperature at pond stocking (May 15) was $15^{\circ} \mathrm{C}$ and then declined to nearly $8^{\circ} \mathrm{C}$ on May 19 . Water temperature then increased to nearly $26^{\circ} \mathrm{C}$ during the ensuing weeks before decreasing as pond harvest approached (Figure 2).

Table 2. Walleye production (number and kilograms per hectare) as well as the presence or absence of filamentous green algae prior to pond harvest among three fertilizer treatments applied to four, 0.72-hectare earthen-substrate ponds at Blue Dog State Fish Hatchery, South Dakota, USA during 2019. Production objectives were at least 104,000 walleye and 32 kilograms per hectare for each pond. The three fertilizer treatments were alfalfa meal (AFM), alfalfa meal plus soybean meal (AFM + SBM), and alfalfa meal plus 28:0:0 (AFM + 28:0:0). AFM treatment was used in Ponds 30 and 34.

\begin{tabular}{cccc}
\hline Treatment or Pond & Number/Hectare & Kilograms/Hectare & Filamentous Green Algae \\
\hline AFM (Pond 34) & 135,625 & 40 & Absent \\
AFM (Pond 30) & 71,666 & 14 & Present \\
AFM + SBM & 0 & 0 & Present \\
AFM + 28:0:0 & 139,791 & 38 & Absent \\
\hline
\end{tabular}



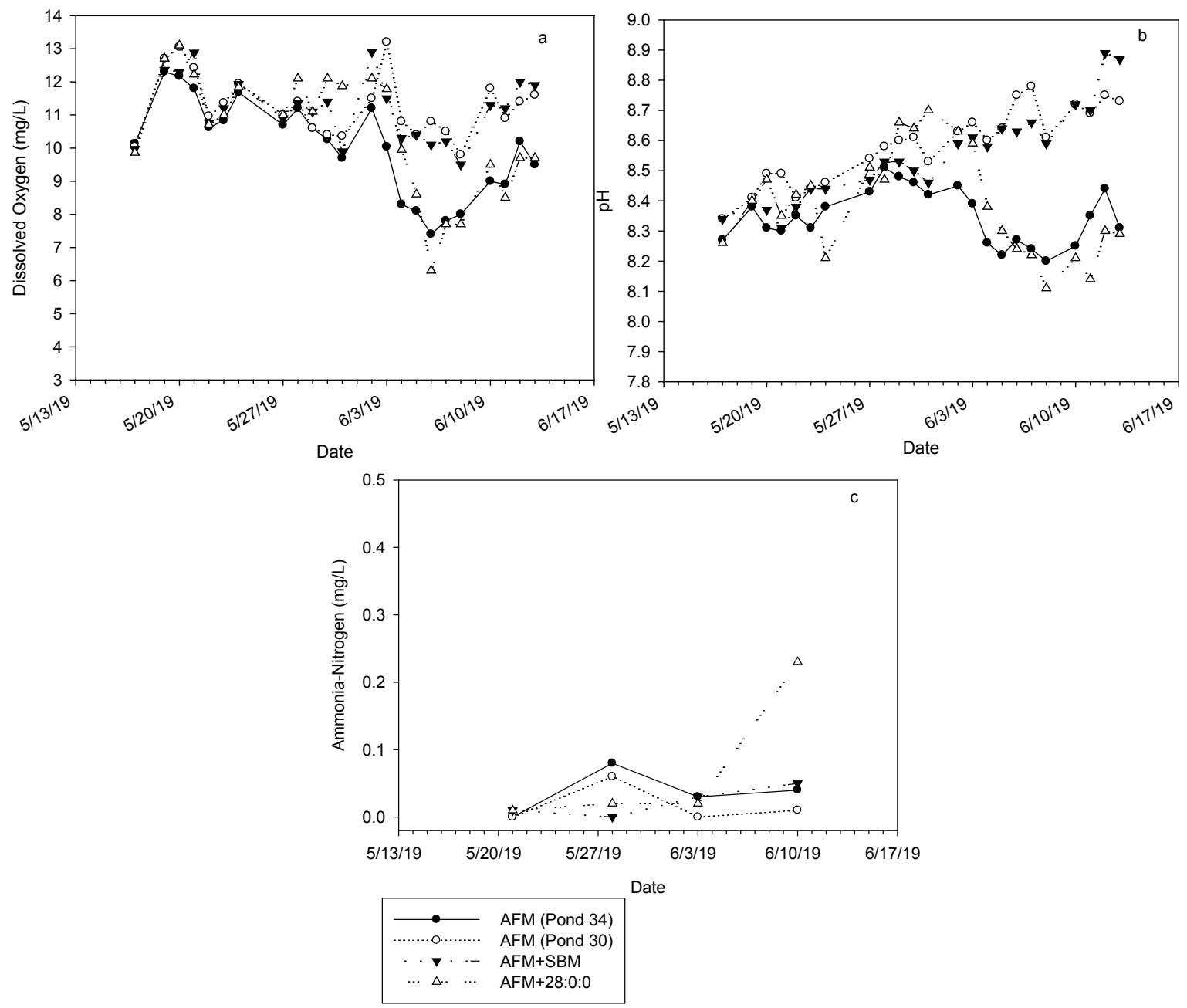

Figure 1. Patterns of dissolved oxygen (a), $\mathrm{pH}(\mathrm{b})$, and ammonia-nitrogen (c) in four, earthen-substrate ponds (0.72 hectare) that received one of three fertilizer treatments; alfalfa meal (AFM), alfalfa meal plus soybean meal (AFM + SBM), and alfalfa meal plus 28:0:0 (AFM +28:0:0). AFM was used in ponds 30 and 34 .

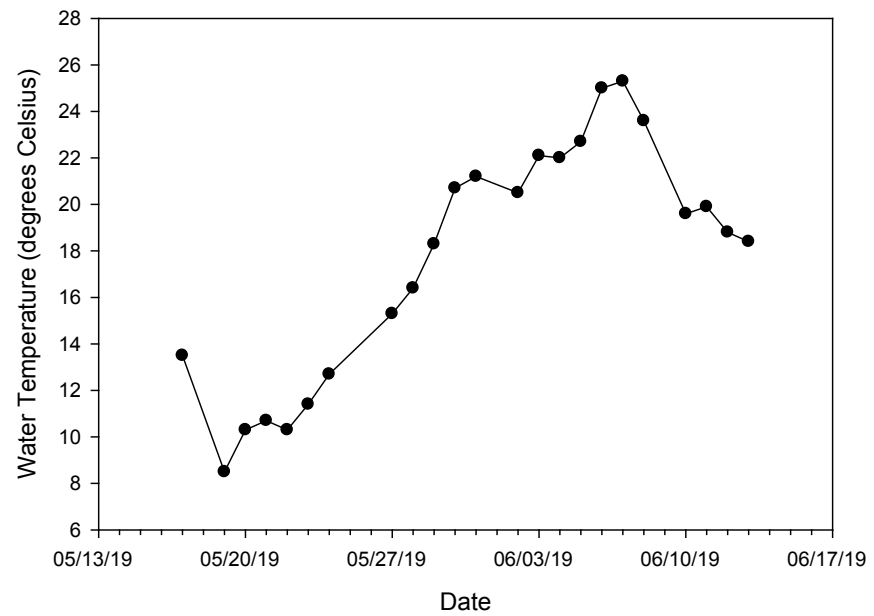

Figure 2. Pattern of water temperature in a 0.72 -hectare, earthen-substrate pond used in the comparison of three fertilizer treatments. Temperature data from only one pond is presented because all ponds used in this comparison were immediately adjacent. 


\section{Discussion}

The presence of filamentous green algae prior to pond harvest consistently resulted in failure to meet walleye production objectives. Filamentous green algae entangle fish [2] and create inefficiencies within food webs that most likely reduce prey for walleye. To support these contentions, the two ponds that did not have filamentous green algae prior to pond harvest exceeded objectives in both number and yield. This highlights the importance of developing fertilizer regimens that do not favor filamentous green algae.

During the second half of the culture period, declines in both $\mathrm{pH}$ and dissolved oxygen corresponded to no filamentous algae preceding harvest and achievement of walleye production objectives. In the absence of the nuisance algae, the decline in dissolved oxygen and $\mathrm{pH}$ resemble a pattern of reduced photosynthetic activity presumably caused by zooplankton overgrazing edible phytoplankton [2] [5] and increased decomposition rate of the alfalfa meal due to higher water temperatures [6]. Whereas, the elevated dissolved oxygen and $\mathrm{pH}$ observed in AFM (Pond 30) and AFM + SBM ponds are likely an artifact of increased photosynthetic activity caused by the inedible, filamentous green algae. The development of filamentous green algae in AFM (Pond 30) and AFM + SBM ponds was most likely underway prior to the last week of the culture period and continued to proliferate as harvest approached [7].

Ammonia-nitrogen remained below $0.1 \mathrm{mg} / \mathrm{L}$ in all earthen-substrate ponds except when 28:0:0 was regularly applied suggesting that it is unlikely for organic fertilizers, even with higher protein content, to produce measurable increases in ammonia-nitrogen. The AFM + 28:0:0 treatment produced water chemistry measurements that most closely resembled those linked to increased production in lined ponds [3], which also typically do not exhibit nuisance algae during pond harvest at this hatchery. The positive results of alfalfa meal supplemented with 28:0:0 warrant future experimentation to include earlier supplementation based on the importance of inorganic nitrogen to preferred phytoplankton [2] [8]. However, caution in regard to ammonia toxicity may need consideration [9].

Limited replication of fertilizer treatments makes definitive conclusions about each treatment unreasonable. Nonetheless, these results describe the increased likelihood of reduced walleye fingerling production in the presence of filamentous green algae and the unpredictability of results when two ponds are treated exactly the same with alfalfa meal. These results also suggest supplementation with 28:0:0 is necessary to increase ammonia-nitrogen concentration above 0.1 $\mathrm{mg} / \mathrm{L}$ in earthen-substrate ponds at this hatchery.

\section{Acknowledgements}

Thanks to J. Broughton, R. Smidt, N. Pool, C. Haabala, A. Gramms, and J. Rudolph for their efforts in the collection and publication of these data. 


\section{Conflicts of Interest}

The authors declare no conflicts of interest regarding the publication of this paper.

\section{References}

[1] Summerfelt, R.C., Clouse, C.P., Harding, L.M. and Luzier, J.M. (1996) Walleye Fingerling Culture in Drainable Ponds. In: Summerfelt, R.C., Ed., Walleye Culture Manual, NCRAC Culture Series 101. North Central Regional Aquaculture Center Publications Office, Iowa State University, Ames, 89-108.

[2] Culver, D.A. (1996) Fertilization Procedures for Pond Culture of Walleye and Saugeye. In: Summerfelt, R.C., Ed., Walleye Culture Manual, NCRAC Culture Series 101. North Central Regional Aquaculture Center Publications Office, Iowa State University, Ames, 115-122.

[3] Ward, M.J. and Blackwell, B.G. (2021) Factors Associated with Increased Walleye Production in Lined Compared to Earthen-Substrate Ponds. Open Journal of Animal Sciences, 11, 50-61. https://doi.org/10.4236/ojas.2021.111005

[4] Ward, M.J., Uphoff, C., Stane, J., Borah, B., Henry, A., Billings, J. and Johnson, B. (2011) Walleye Fingerling Culture in Earthen and Ethylene Propylene Diene Monomer-Lined Ponds. North American Journal of Aquaculture, 73, 1-7. https://www.tandfonline.com/doi/abs/10.1080/15222055.2011.544617

[5] Qin, J.G. and Culver, D.A. (1995) Effect of Young-of-the-Year Walleye (Percidae: Stizostedion vitreum) on Plankton Dynamics and Water Quality in Ponds. Hydrobiologia, 297, 217-227. https://doi.org/10.1007/BF00019286

[6] Boyd, C.E. and Tucker, C.S. (2014) Handbook for Aquaculture Water Quality. Craftmaster Printers, Inc., Auburn, Alabama.

[7] Hartleb, C.F., Johnson, J.A. and Held, J.A. (2012) Walleye and Yellow Perch Pond Fertilization. In: Mischke, C.C., Ed., Aquaculture Pond Fertilization: Impacts of Nutrient Input on Production, Wiley-Blackwell, Oxford, 147-161. https://doi.org/10.1002/9781118329443.ch11

[8] Barcia, J., Kling, H. and Gibson, J. (1980) Experimental Manipulation of Algal Bloom Composition by Nitrogen Addition. Canadian Journal of Fisheries and Aquatic Sciences, 37, 1175-1183.https://doi.org/10.1139/f80-150

[9] Bergerhouse, D.L. (1994) Lethal Effects of Elevated pH and Ammonia on Early Life Stages of Hybrid Striped Bass. Journal of Applied Aquaculture, 2, 81-100. https://doi.org/10.1300/J028v02n03_05. 